\title{
The effects of folic acid on carbon black toxicity in mouse embryo in vivo
}

\author{
Roshdy, H.M and Bibars, M.H \\ Cell Biology Department, National Research Center \\ Dokki, Cairo, Egypt
}

\begin{abstract}
The wide commercial use of carbon black oil (CBO) to produce asphalt and other commercial product has resulted in numerous environmental problems and harmful effects on human health especially during the pregnancy. This study, examining the effect of maternal low and high dietary folate intake and to protect the pregnant women from the developmental toxicity of CBO. Virgin females CD -1 mice were assigned to diets containing either low 500 or $1300 \mathrm{high}$ (control) nmol folic acid/kg for 6 weeks prior to mating and thought out breeding and gestation. From gestation day (GD 6 to 18) females were given by gavage corn oil or CBO at $500 \mathrm{mg} / \mathrm{kg}$ body weight, once daily. On CD 18, mice were weight and killed and the liver removed and weighed. Implantation sites, live and dead fetuses, and resorptions were counted, fetuses were weighed individually and examined for external malformations. The low dietary FA treatment alone and with CBO treatment resulted in low maternal liver as well as low fetal liver folate concentrations relative to the high FA dietary groups. Low FA treatment alone resulted in malformed embryos; there were no embryos affected with malformed in the adequate FA-control group. Low folic acid-CBO treatment resulted in a further increase in the malformed embryos. The percent of malformed embryos in high folic acid-CBO treatment was very low compared to the low folic acid-CBO group. The frequency of chromosomal aberrations in maternal and their fetuses was increased significantly in the low folic-CBO group than high folic acid-CBO group. These results show that the low folate dietary diet with the exposure to the high levels of CBO toxic material in pregnant women significantly increases the developmental and mutagenic toxicity in the small fetuses.
\end{abstract}

\section{Introduction}

The crude oil purification process, in the petroleum industry yields many side-stream products. Such by-products may contain hydrocarbon chains that are more than 20 carbons in length, as well as several other types of molecules, including paraffin's, isoparaffins, olefins, maphthenics, aliphatic hydrocarbons, polycyclic aro-matic nitrogen heterocycles, and hydroxylated policyclic aromatic hydrocarbons (Hansen et al., 2000). In addition to exposure in the work place, pregnant women can be exposed to carbon black oil, as it is found in every day household items, such as hair dyes, pen ink, as well as asphalt tar used in road construction.

There are many reproductive risk of women who live near, or work in, petrochemical plants (Axelsson and
Rylander, 1989). These women represent a population that would more likely be exposed to CBo-type compounds, than women not living or working near petrochemical plants. These investigators observed an increased number of miscarriages in a small subset of workers, they did not demonstrate that work-related or ambient community exposure overall was associated with an increased risk of miscarriage. Adverse pregnancy outcome was also reported in a study of women living near petrochemical plants in china (Chen et al., 1995). Although air pollution caused by the petrochemical industry and automotive fuel was suggested to be a main factor in the reproductive problems of women in Egypt. 
Several animal studies have been conducted to determine the developmental toxicity of clarified oil (CSO), a compound similar to carbon black oil. In one such study, pregnant rats were given oral doses of $2,000 \mathrm{mg} / \mathrm{kg} \mathrm{CSO}$, on selected days of gestation showed increased rates of resorption and developmental defects, such as cleft palate, paw and tail defects (Feuston and Mackerer, 1996). In oral toxicity of other petroleum-based materials (coal-derived liquid fuels), prenatal survival and growth were found to be affected, even though there was no evidence of teratogenic effects in animals dosed at levels $\geq 500$ $\mathrm{mg} / \mathrm{kg} /$ day (Mckee et al., 1987). In Dawley rats, CSO $(8 \mathrm{mg} / \mathrm{kg} /$ day $)$ administered during gestation days (6-15) produced significantly lower thymus weights. Vaginal bleeding, was also observed at the same dosage. At $30 \mathrm{mg} / \mathrm{kg} / \mathrm{day}$, increased frequency of resorption, lower fetal viability and lower fetal weights (Feuston $e t$ al., 1989 and Feuston et al., 1994). Other studies in which CSO was administered topically to rats during 0-19 day of gestation demonstrated that doses ranging from 1 to $250 \mathrm{mg} / \mathrm{kg} /$ day resulted in maternal toxicity that included decreased maternal body weight and vaginal bleeding, both of which were associated with an increased resorption frequency (Hoberman et al., 1995). In both of the above topical studies, the developmental toxicity was observed at dose at which maternal toxicity was also observed.

On the other hand the beneficial role of folic acid during mammalian pregnancy has been well documented over recent years and has been shown to improve birth weight (Lyengar, 1971; Scholl and Johnson, 2000) and prevent the neural tube defects (Milunsky et al.,1989; Czeizel, 1995; Berry et al., 1999). Many studies (Christensen and Rosenblatt, 1995) have shown decreased concentrations of the folic acid vitamin produced resorptions, decreased fetal weight, growth retardation and many other congenital abnormalities (Nelson et al., 1955, 1956 and Nelson, 1960).

There fore, the present study was undertaken to determine (1) the effects of carbon Black oil (CBO) to produce malformations after daily oral treatment in mice during pregnancy (6-18) days of gestation, the approximate period off organsgenesis. The oral treatment was chosen because it is a likely route of 68 exposure (from-eating foods exposed to (CBO). (2) To determine the effect of low and high doses of folic acid to overcome any toxic or teratogenic effects produced by the $(\mathrm{CBO})$.

\section{Materials and Methods:}

\section{Test materials:}

Carbon Blackoil (CBO) was warmed slightly and then mixed with corn oil to make suspensions in the different concentrations. Corn oil served as the control substance in the control group. Folic acid was obtained from sigma chemical company.

\section{Animals:}

Virgin female CD-1 strain mice, weighting 12 to $14 \mathrm{~g}$ were housed in stainless stell cages in a room with a 12-h light/dark cycle at 20 to $23^{\circ} \mathrm{C}$ and $50 \%$ humidity. Animals were fed dites containing either 500 (low) nmol folic acid or 1300 high nmol folic acid $\mathrm{FA} / \mathrm{kg}$ and $1 \%$ succinyl sulfathiazole (SS) is an antibiotic that reduces gut flora responsible for synthesis of a significant amount of folic acid (FA). For 6 weeks prior to mating and throughout breeding and gestation.

Breeding: males from the same strain were placed with females after 6 weeks on their respective diets, (three per cage) overnight and checked on the presence of a vaginal plug. The morning of the day that the plug was found was denoted gestation (Zero day).

\section{Carbon black oil treatment:}

The pregnant females were administered carbon black oil (CBO) orally at a dosage of $500 \mathrm{mg} / \mathrm{kg} /$ day from GD 6 to GD 18; control animals were given equivalent volumes of corn oil by gavaging. A dosage volume of $10 \mathrm{Ml} / \mathrm{g}$ body weight was used. The dose of (CBO) was based on previous work indicating that this dose 
resulted in developmental abnormalities in the swiss webster mice (Hansen, et al, 2000).

Females were observed twice daily for clinical symptoms, on GD $0,8,12,16$, 18 body weights were recorded for each animal.

Tissue collection: on GD 18, animals were anesthetized with $\mathrm{CO}_{2}$ and killed. Maternal liver were rapidly excised, frozen in liquid nitrogen, and stored at $-80^{\circ} \mathrm{C}$ until assayed for folate concentrations. Fetal livers were then collected, frozen with liquid nitrogen and stored at $-80^{\circ} \mathrm{C}$ until analyzed for folate concentrations.

\section{Fetal developmental toxicity:}

The uterus of each animal was removed and weighted and the number of fetuses (live and dead) were recorded. Live fetuses were examined for the presence of external malformations under the distection microscope.

\section{Extraction of folates from maternal and fetal livers:}

Extraction of tissue folates was based on the method of (Horne and Wilson, 1984). Briefly, tissues were boiled in $10 \mathrm{vol}$ of extraction buffer for $10 \mathrm{~min}$ in the dark. The extraction buffer, which consisted of $2 \%(\mathrm{~W} / \mathrm{V})$ sodium ascorbate, $0.2 \mathrm{M} \beta$ mercaptoethanol, 50-mM HEPES, and $50 \mathrm{mM}$ CHES, was boiled prior to use. Cooled liver tissues were homogenized with a tissue homogenizer. Liver homogenates were centrifuged at $40,000 \mathrm{~g}$ for $10 \mathrm{~min}$ at $4{ }^{\circ} \mathrm{C}$. The supernate was removed and centrifuged again for $10 \mathrm{~min}$ at 40,000g and $4^{\circ} \mathrm{C}$. The lipid layer was removed carefully. Liver extracts were filtered through a filter paper and stored at $-20^{\circ} \mathrm{C}$.

\section{Folic acid analysis:}

Assays were performed by L. Casei inoculums in well microtiter plates following the procedure developed by (Horne and Patterson, 1988).

The L- casei inoculum was prepared by mixing I vol of the thawed bacterial suspension with 19 vol of sterile $0.9 \%$ sodium chloride solution. The working buffer was prepared as follows: $3.2 \mathrm{~g}$ of sodium ascorbate were dissolved in $19 \mathrm{~mL}$ of diluted $\mathrm{H}_{2} \mathrm{O}, 1 \mathrm{~mL}$ of $1 \mathrm{M}$ potassium phosphate buffer ( $\mathrm{pH}$ 6-1) was added. Each well of the microtiter plate contained $8 \mathrm{ML}$ of the working buffer. The standard curve ranged from 20 to $120 \mathrm{nmol}$ folic acid in triplicate, with a maximum volume of 60 ML. The volumes of standards and samples were adjusted to $150 \mathrm{ML}$ with sterile diluted $\mathrm{H}_{2} \mathrm{O}$. Folic acid casei medium (150 ML) was added and then 20ML of the Lcasei. The plate was incubated for $18 \mathrm{~h}$ in an oven at $37^{\circ} \mathrm{C}$ and then read at $600 \mathrm{~nm}$.

\section{Chromosomal analysis:}

(a) Pregnant females:

Bone marrow preparations for the analysis of chromosome aberrations in metaphase cells were obtained by the technique of Ford and Hamerton method (1956). On 18 gestation day females were injected to aqueous solution of colchicine $(2.5 \mathrm{mg} / \mathrm{kg} . \mathrm{bw}$ i-p) $3 \mathrm{~h}$ prior scheduled killed by cervical dislocation. The bone marrow cells were aspirated in Hank's buffered salt solution and centrifuged at $1000 \mathrm{~g}$ for $10 \mathrm{~min}$. The pellets obtained were mixed in aqueous solution of $\mathrm{KCl}$ $(0.56 \% \mathrm{w} / \mathrm{v})$ and left for $30 \mathrm{~min}$ at $37^{\circ} \mathrm{C}$. Cells were recentrifuged, fixed in $3: 1$ methanol: glacial acetic acid and dropped on clean slide. Finally, slides were air-dried and stained in $10 \%$ Giemsa stain.

(b) embryos:

chromosomal preparations from embryonic cells were prepared according to Romagnano et al (1985).

Live fetuses were taken after colchicine treatment of pregnant females. Whole embryos were minced with homognizer. Cells were dispersed by repeated pipetting with a pasteur pipette and passed through a tissue filter paper. After centrifuging the cell suspeusion at $1000 \mathrm{rpm}$ for $5 \mathrm{~min}$, cells were treated with $1 \mathrm{~mL}$ hypotonic $(75 \mathrm{mM}) \mathrm{KCl}$ solution for $25 \mathrm{~min}$ at $37^{\circ} \mathrm{C}$, and fixed in methanol/acetic acid (3:1) solution and then air-dried on the slide. The slides were stained for $10 \mathrm{~min}$ in a $5 \%$. Giema solution. Chromosomal aberrations were scored 
blind-fold and at least 50 well-spread metaphase cells/pregnant femal/fetus were analysed. Chromatid/chromosomal gaps, breaks, ring, deletion, and other aberrations were scored.

\section{Statistical analysis:}

For all statistical analysis the pregnant dam and the fetuses were considered the units for comparisons.

Continous variables were analyzed using the two-way analysis of variance (ANOVA) according to Snedcor and Cochran (1990). Least significant differences were used compare between means according to Waller and Duncan (1969) at probability $5 \%$.

\section{Note :}

The means followed by the same alphabetical letters were not significantly different at the probability level of 0.05 .

\section{Results:}

\section{a) Maternal effects:}

There were no maternal deaths in any of the CBO treated animals during the experiment. Clinical symptoms, such as disorientation and general lethargy, were observed in approximately $75 \%$ of the dams dosed $500 \mathrm{mg} / \mathrm{kg} /$ day $\mathrm{CBO}$ and fed low amount of folic acid and in contrast no disorientation were observed in any animals fed high amount of folic acid. However, maternal weights gain were decreased by low folic acid and CBO treatment (table 1) than control groups throughout gestation periods. Animals fed high folic acid and treated with corn oil had higher body weight than the low folic-acid oil group. Also there was a significant increase in maternal weights in the high folic acidtreated $\mathrm{CBO}$ group than low folic acidtreated $\mathrm{CBO}$ group.

There was a significant increase between folate and $\mathrm{CBO}$ with respect to relative maternal liver weight. The low dietary folic acid treatment was associated with an increase in relative maternal liver weights, the highest values occurring in animals exposed to $\mathrm{CBO}$ Table (1). In contrast in the high dietary folic acid treatments there was no significant difference in the liver weights between control and CBO group.

On the other hand the hepatic folate concentration groups were significantly lower in the low folic acid control and CBO treatment groups than in high folic acid groups the low hepatic folate concentrations observed in the low dietary folic acid groups providing evidence that a functional folate deficiency had been induced, while in both high dietary folic acid control group and $\mathrm{CBO}$ group the hepatic folate concentrations increased significantly but the lowest value was in the high folic acid$\mathrm{CBO}$ group than in their control.

\section{b) Fetal effects:}

Both low dietary folate control and CBO groups positively affected the number of implantations (Table 2). There was a significant interaction between folate and CBO with respect of frequency of fetal death and fetal malformations. The percent of live fetuses was highest in the high folic acid control group. The number of malformed fetuses was highest in the low folic acid-CBO group. Total sites affected (dead and malformed fetuses) were significantly affected by both $\mathrm{CBO}$ and folic acid treatments, the highest occurrence being in the low folic acid-CBO group.

CBO treatments were associated with lower fetal weights in the low folic acid group. Fetal weights were lowest in the low dietary folic acid -CBO group. Fetal liver folate concentrations were significantly affected by maternal dietary folic acid intake. Fetal liver folate values were 
Table (1): The influence of dietary folic acid intake (500 and $1300 \mathrm{nmol}$ folic acid/kg diet) on the effects of carbon black oil on maternal parameters.

\begin{tabular}{|l|l|l|l|l|}
\hline \multirow{2}{*}{ Treatments } & \multicolumn{2}{|l|}{$\begin{array}{l}\text { Low folate } \\
500 \mathrm{nmol} / \mathrm{kg}\end{array}$} & \multicolumn{2}{l|}{$\begin{array}{l}\text { High folate } \\
1300 \mathrm{nmol} / \mathrm{kg}\end{array}$} \\
\cline { 2 - 5 } & Corn oil & CBO & Corn oil & CBO \\
\hline Animals(n) & $(25)$ & $(25)$ & $(25)$ & $(25)$ \\
Maternal weight (g) & & & & \\
Day 0 & 25.5 & 26.50 & 26.72 & 27.00 \\
Day 8 & 27.7 & 28.3 & 28.30 & 28.72 \\
Day 12 & 30.3 & 28.5 & 31.3 & 30.21 \\
Day 16 & 34.5 & 30.5 & 35.93 & 32.65 \\
Day 18 & 40.57 & 36.2 & 45.57 & 43.9 \\
Non gravid material Body weight GD (8) & 30.2 & 29.0 & 32.72 & 32.00 \\
g & & & & \\
Net maternal Weight gain (g) & 4.7 & 2.5 & 6 & 5 \\
Mean liver weight (g) & 7.50 & 8.50 & 6.40 & 6.35 \\
Maternal liver floater & 4.65 & 4.55 & 9.54 & 9.26 \\
Total maternal liver folate & 12.91 & 11.70 & 17.75 & 17.15 \\
\hline
\end{tabular}

CBO was given orally at a dose of $500 \mathrm{mg} / \mathrm{kg} /$ body weight-between gestation days 6 and 18 .

lower in the low folic acid-control group and in the low folic acid-CBO group, compared to their respective high folate groups.

The influence of dietary folic acid and CBO treatment on the incidence of fetal malformations is summarized in Table (3). The incidence of clef palate was affected by both the amount of folic acid in diet and CBO treatments. The occurrence of cleft palate and Excencephaly was most prononnced in low dietary folic acid control group than high folic acid control group.
CBO significantly elevated the occurrence of cleaft palate and Excencephaly in both dietary groups. The highest frequency of fetuses affected by both cleft palate and Excencephaly was found in low dietary folic acid CBO group than the high-folic acid CBO group.

Cytogenatic analysis: (Maternal and fetal):

The frequencies of chromosomal aberrations (Structural and numerical) in maternal bone marrow cells (Table 4) was significantly

Table (2): The influence of dietary folic acid intake (500 and $1300 \mathrm{nmol}$ folice acid/kg diet on the effects of carbon black on embryos at day 18 of gestation

\begin{tabular}{|l|l|l|l|l|}
\hline \multirow{2}{*}{ Treatments } & Low folate & High folate \\
\cline { 2 - 5 } & Corn oil & CBO & Corn oil & CBO \\
\hline No. of pregnant females & $(25)$ & $(25)$ & $(25)$ & $(25)$ \\
\hline No. of implantation & 220 & 235 & 280 & 240 \\
\hline No. Live fetuses & 217 & 228 & 279 & 237 \\
\hline$\%$ & $98.6 \%$ & $97 \%$ & $99.6 \%$ & $98.7 \%$ \\
\hline Malformed fetuses & 5 & 20 & 3 & 5 \\
\hline$\%$ & $2.3 \%$ & $8.7 \%$ & $1.1 \%$ & $2.3 \%$ \\
\hline No. dead fetuses & 3 & 7 & 1 & 3 \\
\hline$\%$ & $1.38 \%$ & $3.07 \%$ & $0.35 \%$ & $1.26 \%$ \\
\hline Mean fetal weight $(\mathrm{g})$ & 1.3 & 1.0 & 1.40 & 1.33 \\
\hline Fetal liver folate $\mathrm{nmol} / \mathrm{gm}$ & 1.87 & 1.72 & 5.80 & 5.89 \\
\hline
\end{tabular}

CBO was given orally at a dose of $500 \mathrm{mg} / \mathrm{kg} /$ body weight daily, between gestation day 6 and 18 . 
Table (3): The influence of dietary folic acid intake (500 to $1300 \mathrm{nmol}$ folic acid $\mathrm{kg} /$ diet) CBO on fetal malformations.

\begin{tabular}{|c|c|c|c|c|}
\hline \multirow{2}{*}{ Treatments } & \multicolumn{2}{|c|}{ Low folate } & \multicolumn{2}{|c|}{ High folate } \\
\hline & Corn oil & $\mathrm{CBO}$ & Corn oil & $\mathrm{CBO}$ \\
\hline Fetuses (n) & $(25)$ & $(25)$ & $(25)$ & $(25)$ \\
\hline Fetal abnormalities & & & & \\
\hline Cleft palate & $3 / 217$ & $15 / 228$ & $3 / 279$ & $2 / 237$ \\
\hline Excencephaly & $3 / 217$ & $7 / 228$ & $2 / 279$ & $3 / 237$ \\
\hline $\begin{array}{l}\text { Combined cleft palate and } \\
\text { excencephaly }\end{array}$ & $1 / 217$ & $2 / 228$ & $2 / 279$ & $0 / 237$ \\
\hline Total affected fetuses & $5 / 217$ & $20 / 228$ & $3 / 279$ & $5 / 237$ \\
\hline
\end{tabular}

CBO was given orally at a dose of $500 \mathrm{mg} / \mathrm{kg} /$ body weight daily, between gestation day 6 and 18 .

increased in low dietary folic acid control and CBO groups than high dietary folic acid groups and the highest values were in the low dietary folate-CBO group. The chromosomal aberrations in the fetuses without malformation Table (5) shows that there is a significant increases in the frequencies of chromosomal aberrations in low folic acid control and CBO groups than high dietary folic acid groups but these increases were lower than the frequencies of chromosomal aberrations in the fetuses which were affected by malformations in both low dietary and high dietary folic acid controls and CBO groups (Table 6) In all treatments with $\mathrm{CBO}$ and folic acid. The most frequent chromosomal aberrations observed were chromatid gagps and chromatid breaks, followed by deletions, rings and endomitosis. 
Table (4): The effect of folic acid intake and CBO on the chromosomal aberrations of bone marrow cells of mothers.

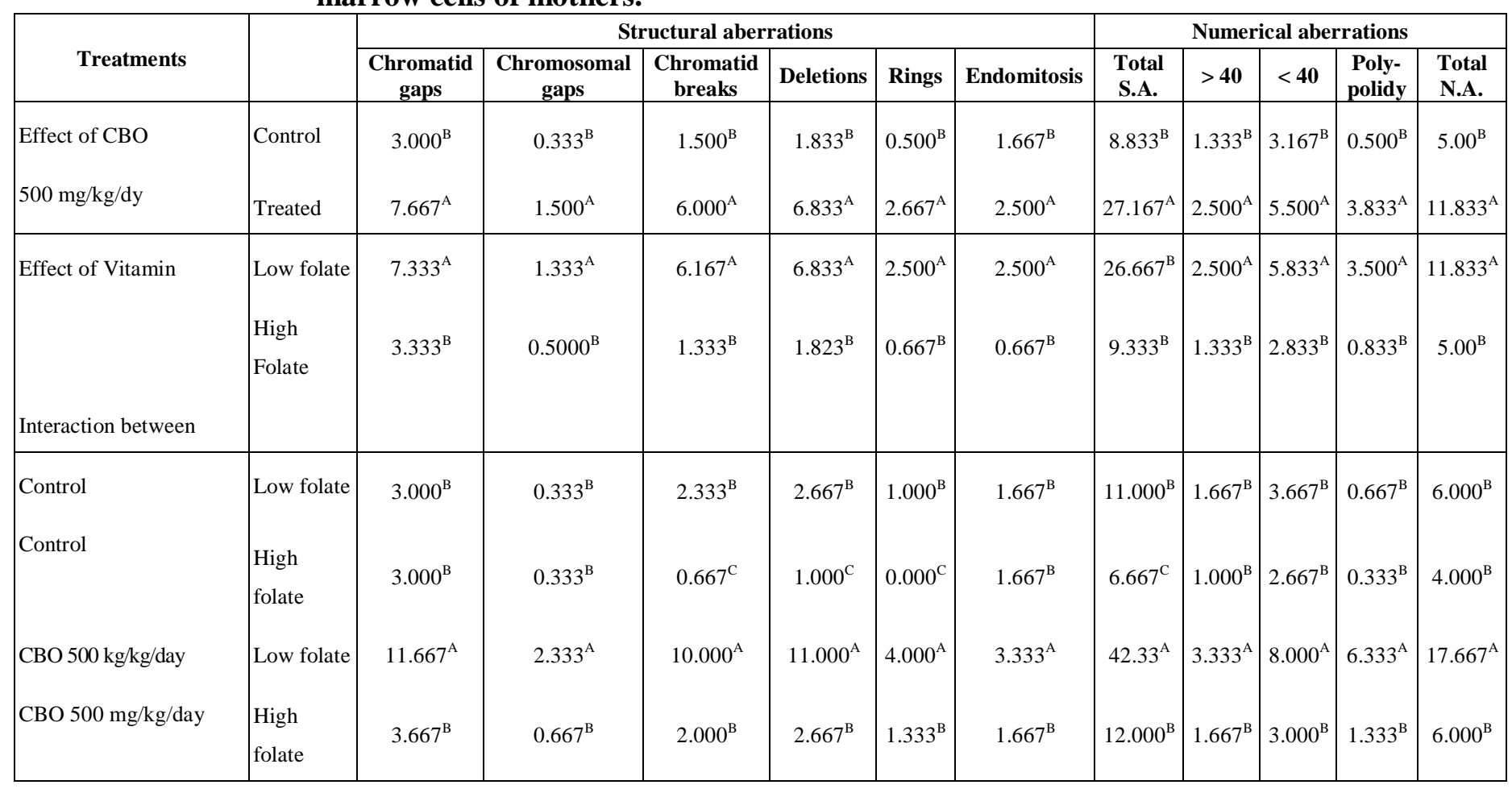

No of Animals 25 for each group.Means followed by different alphabetical letters were significant at probability $5 \%$.

Table (5): The effect of folic acid intake and CBO on the chromosomal aberrations of normal embryo cells

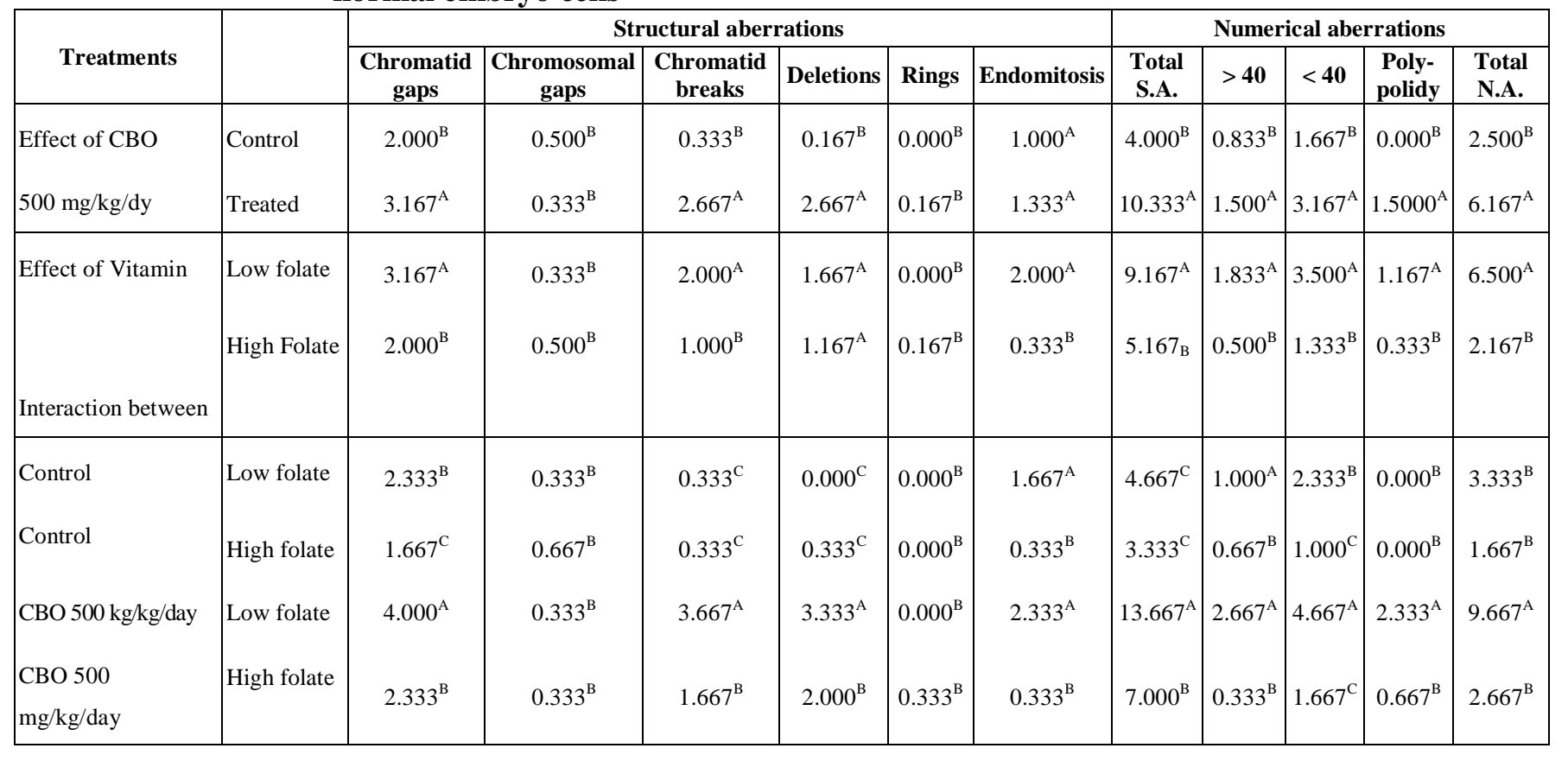

No of Animals 25 for each group.Means followed by different alphabetical letters were significant at probability $5 \%$. 
Roshdy, H.M and Bibars, M.H

Table (6): The effect of folic acid intake and $\mathrm{CBO}$ on the chromosomal aberrations of malformed (abnormal) embryo cells.

\begin{tabular}{|c|c|c|c|c|c|c|c|c|c|c|c|c|}
\hline \multirow[b]{2}{*}{ Treatments } & & \multicolumn{6}{|c|}{ Structural aberrations } & \multicolumn{5}{|c|}{ Numerical aberrations } \\
\hline & & \begin{tabular}{|c|}
$\begin{array}{c}\text { Chromatid } \\
\text { gaps }\end{array}$ \\
\end{tabular} & $\begin{array}{c}\text { Chromosomal } \\
\text { gaps }\end{array}$ & \begin{tabular}{|c}
$\begin{array}{c}\text { Chromatid } \\
\text { breaks }\end{array}$ \\
\end{tabular} & Deletions & Rings & Endomitosis & $\begin{array}{l}\text { Total } \\
\text { S.A. }\end{array}$ & $>40$ & $<40$ & $\begin{array}{l}\text { Poly- } \\
\text { polidy }\end{array}$ & $\begin{array}{l}\text { Total } \\
\text { N.A. } \\
\end{array}$ \\
\hline Effect of CBO & Control & $2.167^{\mathrm{B}}$ & $0.000^{\mathrm{B}}$ & $0.667^{\mathrm{B}}$ & $1.000^{\mathrm{B}}$ & $0.000^{\mathrm{B}}$ & $1.167^{\mathrm{B}}$ & $5.000^{\mathrm{B}}$ & $0.833^{\mathrm{B}}$ & $1.500^{\mathrm{B}}$ & $0.167^{\mathrm{B}}$ & $2.500^{\mathrm{B}}$ \\
\hline $500 \mathrm{mg} / \mathrm{kg} / \mathrm{dy}$ & Treated & $4.500^{\mathrm{A}}$ & $2.000^{\mathrm{A}}$ & $4.333^{\mathrm{A}}$ & $4.500^{\mathrm{A}}$ & $2.000^{\mathrm{A}}$ & $2.000 \mathrm{~A}$ & $19.333^{\mathrm{A}}$ & $1.000^{\mathrm{A}}$ & $5.333^{\mathrm{A}}$ & $3.000^{\mathrm{A}}$ & $9.333^{\mathrm{A}}$ \\
\hline \multirow[t]{2}{*}{ Effect of Vitamin } & Low folate & $3.500^{\mathrm{A}}$ & $1.833^{\mathrm{A}}$ & $3.333^{\mathrm{A}}$ & $3.833^{\mathrm{A}}$ & $2.000^{\mathrm{A}}$ & $3.167^{\mathrm{A}}$ & $17.667^{\mathrm{A}}$ & $1.500^{\mathrm{A}}$ & $4.500^{\mathrm{A}}$ & $2.333^{\mathrm{A}}$ & $8.333^{\mathrm{A}}$ \\
\hline & $\begin{array}{l}\text { High } \\
\text { Folate }\end{array}$ & $3.167^{\mathrm{A}}$ & $0.167^{\mathrm{B}}$ & $1.667^{\mathrm{B}}$ & $1.667^{\mathrm{B}}$ & $0.000^{\mathrm{B}}$ & $0.000^{\mathrm{B}}$ & $6.667^{\mathrm{B}}$ & $0.333^{\mathrm{B}}$ & $2.333^{\mathrm{B}}$ & $0.833^{\mathrm{B}}$ & $3.5000^{\mathrm{B}}$ \\
\hline \multicolumn{13}{|l|}{ Interaction between } \\
\hline Control & Low folate & $1.667^{\mathrm{C}}$ & $0.000^{\mathrm{B}}$ & $1.000^{\mathrm{C}}$ & $1.333^{\mathrm{C}}$ & $0.000^{\mathrm{B}}$ & $2.333^{\mathrm{B}}$ & $6.333^{\mathrm{C}}$ & $1.000^{\mathrm{B}}$ & $2.000^{\mathrm{C}}$ & $0.000^{\mathrm{B}}$ & $3.000^{\mathrm{C}}$ \\
\hline Control & High folate & $2.667^{\mathrm{B}}$ & $0.000^{\mathrm{B}}$ & $0.333^{\mathrm{C}}$ & $0.667^{\mathrm{C}}$ & $0.000^{\mathrm{B}}$ & $0.000^{\mathrm{C}}$ & $3.667^{\mathrm{D}}$ & $0.667^{\mathrm{C}}$ & $1.000^{\mathrm{D}}$ & $0.333^{\mathrm{B}}$ & $2.000^{\mathrm{D}}$ \\
\hline CBO $500 \mathrm{~kg} / \mathrm{kg} /$ day & Low folate & $5.333^{\mathrm{A}}$ & $3.667^{\mathrm{A}}$ & $5.667^{\mathrm{A}}$ & $6.333^{\mathrm{A}}$ & $4.000^{\mathrm{A}}$ & $4.000^{\mathrm{A}}$ & $29.000^{\mathrm{A}}$ & $2.000^{\mathrm{A}}$ & $7.000^{\mathrm{A}}$ & $4.667^{\mathrm{A}}$ & $13.667^{\mathrm{A}}$ \\
\hline CBO $500 \mathrm{mg} / \mathrm{kg} /$ day & High folate & $3.667^{\mathrm{B}}$ & $0.333^{\mathrm{B}}$ & $3.000^{\mathrm{B}}$ & $2.667^{\mathrm{B}}$ & $0.000^{\mathrm{B}}$ & $0.000^{\mathrm{C}}$ & $9.667^{\mathrm{B}}$ & $0.000^{\mathrm{C}}$ & $3.667^{\mathrm{B}}$ & $1.333^{\mathrm{B}}$ & $5.000^{\mathrm{B}}$ \\
\hline
\end{tabular}

No of Animals 25 for each group.Means followed by different alphabetical letters were significant at probability $5 \%$.

\section{Discussion}

The differences in maternal body weight after treatment with $\mathrm{CBO}$ were probably attributable to both increased resorption frequency and decreased body weight gain also the low folic acid treatment used in this study substantially reduced the size of the pool of readily available folate as indicated by hepatic tissue folate concentrations. Therefore, these females were expected to weight less than the animals that fed high dietary folic acid and carried live fetuses to GD 18.

Although understanding the mechanism concerning the specific toxic pathway of (CBO). Prudhoe Bay crude oil (PBCO) is a mixture similar to $\mathrm{CBO}$ in containing aliphatic, aromatic, and heterocyclic fractions. The toxicity of PBCO has been attributed to the inhibition of the succinate dehyrogenase supported electron transfer activities in respicatory function (Khan et al., 1986).

Previously, (Hansen et al, 2000) reported that giving CD-1 mice CBo orally from GD 6 through $15(400 \mathrm{mg} / \mathrm{kg} /$ day $)$ resulted in fetal growth retardation, an increased incidence of fetal malformations including cleft palate and exencephaly, and an increased frequency of prenatal death. No one from the previous studies discuss the mutagenic effects of $\mathrm{CBO}$ on the chromosomes of pregnant females and their embryos and No one studied the protective effects of folic acid on $\mathrm{CBO}$ toxicity.

The present work demonstrates the developmental and mutagenic toxicity of $\mathrm{CBO}$ on the pregnant females and their fetuses if CBO dosed orally in a dose of $500 \mathrm{mg} / \mathrm{kg} /$ day during pregnancy, also we demonstrates the protective effect of folic acid (folinic acid) on long term, when the females fed a low and high dietary folicacid concentrations.

We found that the reduced amount of folic acid in diet reduced maternal folate status led to an appreciable reduction in the fetal liver folate concentrations and this led to fetal developmental toxicity especially 
when these pregnant females exposed to toxic material such as $\mathrm{CBO}$ which led to more developmental toxicity. In rats, (Thenen, 1979) has reported that liver folate concentrations were more affected than the maternal liver folate concentrations, also (Lin, 1991) had also reported that in rats, fetal liver folate concentrations can be influenced by maternal dietary folate intake. Collectively, these data suggested that the fetus doses not have preferential access to maternal folate stores.

In this study we found also that the adequate amount of folic acid which was given to the pregnant females can reduce the toxic effects of $\mathrm{CBO}$ on mothers and their fetuses, this protective effects of folic acid on the incidence of developmental and mutagenic toxicity suggested that folicacid-containing multivitamin supplementation after protection against the recurrence and occurrence of chromosomal and developmental toxicity (Shaw et al., 1995). So, in this study we analysis the chromosomal aberrations caused by CBO treatment in normal and malformed fetuses, we found that there is a significant increase in the values of chromosomal aberrations in malformed fetuses when comparing the values with unaffected fetuses but still the valuses of low dietary folic acid in the both affected and unaffected increased than the high-dietary folic acid CBO treatments.

Mechanistically, given the role of folate in pyrimidine and purine synthesis, we have proposed that alow folate status may lead to a nucleotide imbalance that would affect the rate of cell proliferation and differentiation. We found that the additional stress of CBO toxicity occurring via a folate-dependent pathway would enhance cytogentic damage in vivo.

In summary, $\mathrm{CBO}$ is toxic material to pregnant women when exposed to $\mathrm{CBO}$ at high dose/volume effects $(500 \mathrm{mg} / \mathrm{kg})$ during the pregnancy, the $\mathrm{CBO}$ effects are varied and include maternal and fetal development and mutagenic toxicity also the low dietary folic acid diet acted synergistically with the compromised maternal and fetal folate status to adversely affect fetal developmental malformations with $\mathrm{CBO}$. The adequate dietary folate intake during the pregnancy prevent the environmental factors such as increased $\mathrm{CBO}$ exposure and can reduced its toxicity.

\section{References}

1. Axelsson, G; Rylander, R. Outcome of pregnancy in women engaged in Laboratory Work at a petrochemical Plant. Am J Ind Med. 1989 (16): 539545.

2. Berry, RJ; Li, 2; Moore, CA and Wang, H. preventation of reucal-tube defects with folic acid in China. N Eng. L.J. Med. 1999, (34), 1485:1490.

3. Chen, Z; Chen, $\mathrm{C}$ and Dong, $\mathrm{S}$. Epidemiological studies on risk for adverse pregnancy outcomes in women neighboring apetrochemical works. Ching Hua YU Fang I Hsueh Tsa Chih. (1995), (29): 209-212.

4. Christensen, $B$ and Rosenblatt, DS. Effects of folate deficiency on embryonic development. Daillieve's Clin Haematol. 1995, (8) 617-637.

5. Czeizel, AE. Limb-reduction defects and folic acid supplementation. Lancet (1995), 345-932.

6. Feuston, MH and Mackerer, ER. Developmental toxicity of clarified slurry oil, syntower bottoms, and distillate aromatic extract administered as a single oral dose to pregnant rats. J Toxciol Environ Health. 1996, (49): 45-66.

7. Feuston, MH; Kerstetter, SL and Singer, EJ. Developmental Toxicity of Clarified Slurry oil applied dermally torats. Toxicol Ind Health 1989, (5): 587595.

8. Feuston, MH; Low, LK and Hamitton, CE. Correlation of systemic and developmental toxicities with chemical component classes of refinery strems. Fundam Appl Toxciol. 1994, (22): 622630.

9. Ford, C.E. and Hamerton, J.L. Acolchicine, hypotomic citrate squash sequence for mammalian chromosomes. Stain Technol. 1956 (3): 247-251.

10. Hansen, J.M.; Reyno LDS, P.R. and Seegmiller, R.E. Developmental toxicity of carbon Black oil in mice. Teratology, 2000; (62): 227-252.

11. Hoberman, A; Christian, $M$ and Koshchier, F. Developmental toxicity study of clarified slurry oil (CSO) in the rat. Fundam. Appl. Toxciol. 1995; (28): 34-40. 


\section{Roshdy, H.M and Bibars, M.H}

12. Horne DW and Patterson D. Lactobacillus casei micro-biological assay of folic acid derivatives in 96-well microtiter plates. Clin Chem. (1988), (34): 2357-9.

13. Horne, DW and Wilson, SD. Highperformance liquid chromatographic determination of the distribution of naturally occurring folic acid derivatives in rat liver. Anal Biochem 1984 (142): 529-535.

14. Khan, S; Payne, JF and Rahimtula, AD. Mechanisms of petroleum hydrocarbontoxicity: functional changes in rat liver mitochondria after exposure to a Prudhoe Bay Crude oil. Toxciol Lett 1986, (32) 141-146.

15. Lin,Gw. J. Effect of dietary folic acid level and gestional ethanol consumption on tissue folate contents and rat fetal development. Nutr. Res 1991; (11): 22330.

16. Lyengar, L. Folic acid requirements of Indian pregnant women. Am. J. Obstet Gynecol. 1971, (111), 13-16.

17. Mckee PH; Plutnick, RT and Traul, KA. Assessment of the potential reproduction and subchronic toxicity of EPS coal liquids in Sprague-Dowley rats. Toxicology 1987, (46): 267-280.

18. Milunsky, A; Jick, H and Bruell, CL. Multivitamin/folic acid supplementation in early pregnancy reduced the prevalence of neucal tube defects. JAMA. 1989, 262:2847-2852.

19. Nelson, MM. Teratgoenic effects of pteroyl ghtamic acid deficiency in the rat. In: Wolstenholme on congenital
Malformations. Boston. Little, Broudrs and Company. 1960, p. 134-157.

20. Nelson, MM; Wright, HV and Evans, HM. Multiple Congenital abnormalities resulting from transitory deficiency of pteroylglutamic acid during gestation in the rat. J Nutr 1955 56:349-370.

21. Nelson, MM; Wright, HV; Baird, CDC and Evans, HM. Effect of 36-hr period of pteroylglutamic acid deficiency on fetal development in the rat. Proc Soc Exp Biol Med 1956 92: 554-556.

22. Romagnano, A; Richer, C.L and perrone, M.A. direct technique for the preparations of chromosome from early embryo. Can. J. Genat. Cytel, 1985, (27): 365-369.

23. Scholl, T.O. and Johnson, W.G. Folic acid influence on the outcome of pregnancy. Am. Chin Nutr. 2000, (59): 536-545.

24. Shaw GM; Lammer EJ; Wasserman CR; O'Malley CD, Tolarova, MM. Risks of orofacial clefts in children born to women using multivitamins containing folic acid periconceptionally. Lancet 1995; (345): 393-396.

25. Snedecor, G.W and W.G cochran. Statistical methods, 9 ${ }^{\text {th }}$ ed. 1990 lowa state Unive. Press, lowa, USA.

26. Thenen SW. Correlation between maternal and fetal folic acid status at day 21 of gestation in rats. Nutr Rep Int. 1979 (19): 267-274.

27. Waller, A. and D.B. Duncan. Multiple range and multiple test. Biometries. 1969, (11): 1-24. 


\title{
تأثير فيتامين الفوليك أسيد على أخطار الكربون الأسود في أجنة الفئران
}

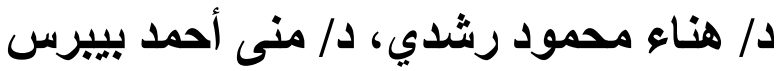

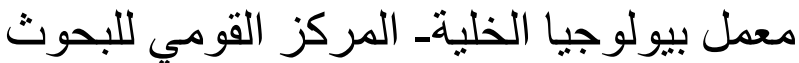

الكربون الأسود هو إحدى نواتج صناعات البترول و عو ادم السيار ات ويدخل في صناعة

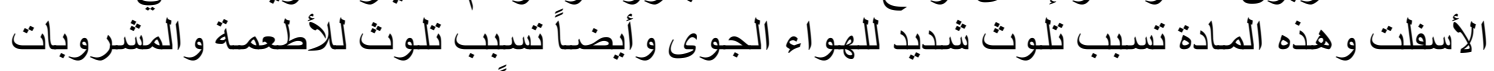

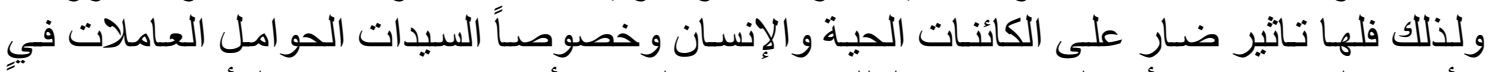

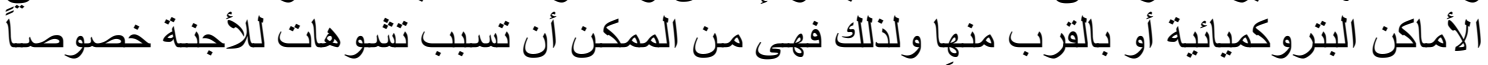

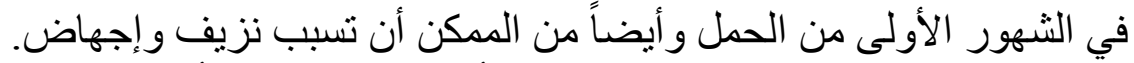

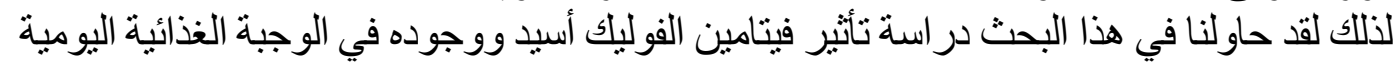

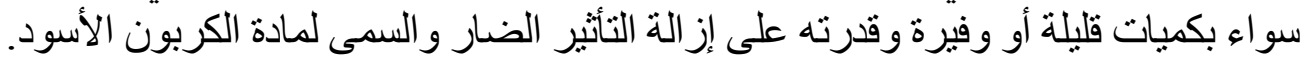

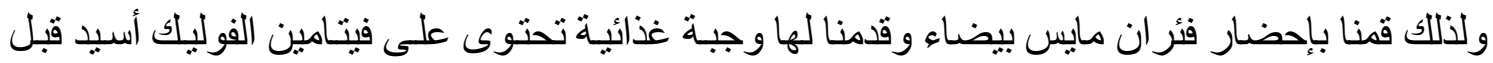

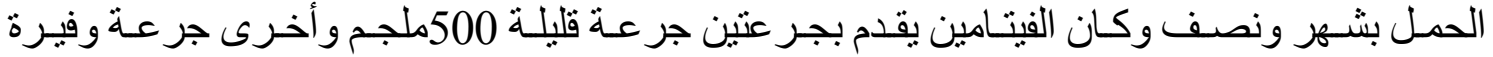
1300ملجم مع استمر ار أخذ الفيتامين أثناء الحمل، ثم أحضرنا مادة الكربون الفين الأسود 500ملجم و أعطيناها

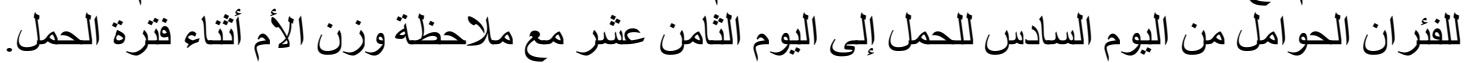

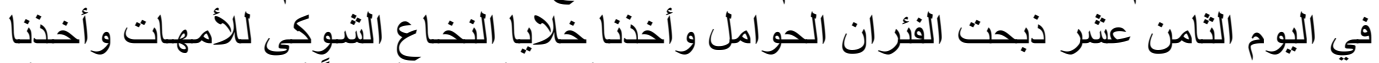

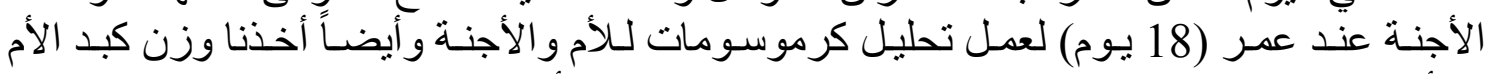

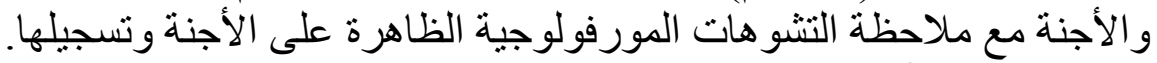

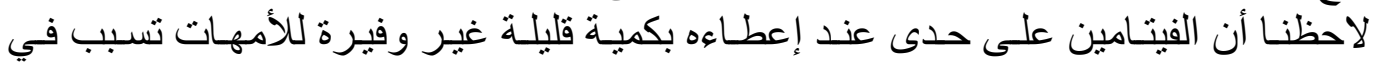

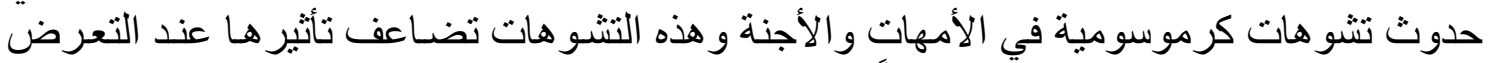

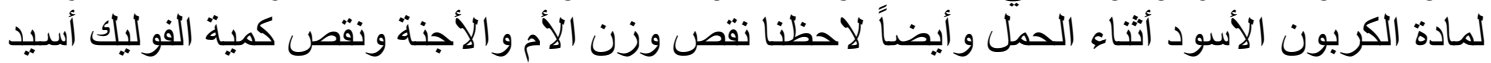

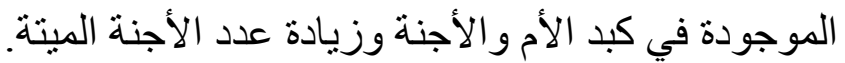

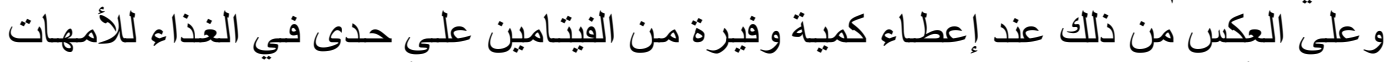

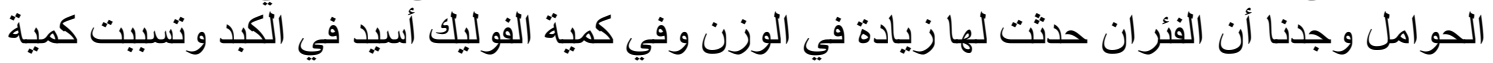

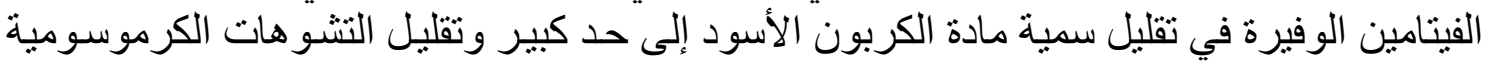

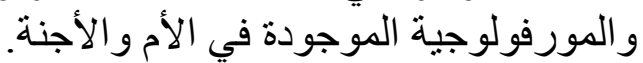

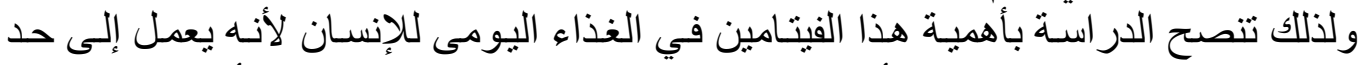

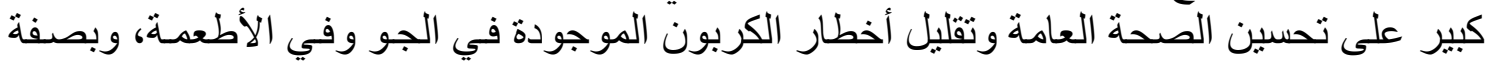

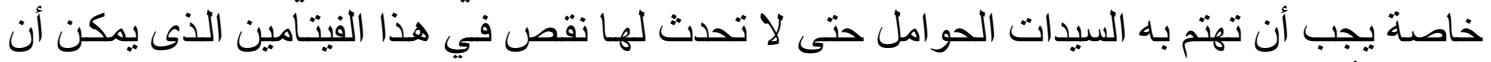
يسبب للأجنة تشو هات كبيرة. 